\title{
Research, Technology and Innovation: The Bedrock for Global Development
}

\author{
Article by Emmanuel O. Chukwu \\ Nursing, Texila American University, Nigeria \\ Email: emmanwaguy42@yahoo.com
}

\section{Synopsis}

The above three concepts are a product of scientific ideas. Global development can only be achieved with solid reliance on research, technology and innovation. The three concepts represents the only way for developing the world in order to foster economic, education, environmental, medical and societal development at large (Cramer and Zegveld, 1991). Development in science and technology are fundamentally altering the way people live, connect, communicate and transact, with profound effects on economic development (LeeRoy, 2012). According to V. Samuel cited in Jubel (2012), 'Science is the key which unlocks for humankind the store houses of nature'. Obsessed by the quest to improve his life; to add values and make a paradigm shift in nature, a global change has smiled to the prevailing efforts of man. He has not just learnt how to cut stones in to blocks but how to use them in a better published form to build edifices. This is development!

A sweep in to the history of the computer system marshals out litanies of stages that the computing system had undergone before it came to the taste of the modern man. Right from the times of the ancient Babylon which is now known as 'Iraq', the so-called abacus machine was invented, one of the earliest devices used by the primitive man to improve his state of living, calculation. He was not satisfied by this innovation; he enthusiastically delved more in to research and found out that addition and subtraction could be better done using a machine which was named after the inventor, 'Napier bone' by John Napier, precisely in 1614 . This technological advancement and product of research work was spiced by the innovation of the inquisitive man.

Hovering round your mind now is how and if these changes have helped in global development. I crave your indulgence to exercise patience for a brief prelude and chronicle of the modern technology which could serve as a frame work to illustrate the above topic under discourse. So, in 1623, a German professor of the University of Tubingen in Germany, Wilhelm Schikeard constructed the first mechanical calculator which worked only with six digits. Advancement in technological innovation is here again! Yet, man was not satisfied

with this as his curiosity still dragged him to the idea of research using his curious mind. It was in 1642 that a French philosopher called Blaise Paschal invented a machine that was named after him, the 'Paschal Calculator'. He actually invented it to help his father who was a tax collector. Here, we could see how innovations served human problems.

History yawned happily on us when the great British mathematician, Charles Babbage in the 19th century (1820 and 1821) worked out the principles of the modern digital computer. This great intellectual introduced an idea that helped to solve complicated mathematical problems. Historians believe that Babbage and his group were the first people to invent the modern digital computer.

With the advancement of Information and Communication Technology (ICT), this is of course the conception of an innovation, pieces of material like journals, articles, updates etc could serve all and sundry as well as students well when they hunger for information. On the internet we find unadulterated definition of scientific work as pieces of vital information compete for web space for the person who makes a research work.

The nucleus of this research work is technology, while the vital force behind its advancement is innovation, which is man's usage of his idea! As I set my fingers scrolling up and down the screen of my personal computer (PC) now is as a result of technology, the 
South American Journal of Academic Research

Special Issue May 2016

computer system; whereas the installed information that I source for is a result of an intellectually articulated innovative idea as well as a confirmed research work.

To then ask, ponder or wonder how these enormous and numerous scientific works have become the bedrock of global development is like contemplating whether a monkey eats banana. The result of this is obvious! Today, we talk and experience globalization. Is it not development, stemming up from research, technology and human innovation?

One of the phenomena identified as the major dynamics of change and consequent global development in the 21st century is globalization. The term 'globalization' precisely describes the process of increasing interconnection between societies such that events in one part of the world have effects on peoples and societies far away. Thus, in an angular perspective, we can say that a globalized world is a developed world. It is one in which political, economical, social, educational and cultural events become more and more interconnected, and also one in which the impacts of these events in one society affects extensively the lives of people in other societies.

We won't be outside the track (this topic) to understand into to the concept of globalization, as it would form a tapestry on which the colored thread of this write-up could be woven. Therefore, what is globalization? In this context, we shall approach the definition using two (among five) of Fongwan Severin's delineation.

According to Fongwan (2013), globalization could be considered as universalization. In this link, the word 'global' is used in the sense of being 'worldwide' and globalization is seen as the process of spreading various objects and experiences to people at all corners of the earth. A classic example of this would be the spread of computing, television, etc.

In the second delineation, globalization could be equated with internalization. In this context, globalization is viewed simply as an adjective to describe cross-border relations between countries. It describes growth in international exchange and interdependence. Therefore, with growing flows of trade and capital investment, development is defined.

\section{Prognosis}

In rummaging in to the treatment of this topic, I could psych opposing minds: that the aforementioned concepts can never be the bed rock of global development nor the stepping stone to achieving that; they are rather impediments to global development and reformation for reasons which we shall discuss subsequently. More so, if I don't stripe naked this judgment in a thesis and consequently counteract the view in an antithesis and synthesize the two in a synthesis, my write-up here would be epileptic and half baked. Therefore, I shall begin by stating some of the concerns of those who disavow the possibility of advancement and a global development through research, technology and innovations by stating their thesis. Then I shall go on to project the counter views in an antithesis while I shall make some efforts to synthesize the two views in a synthesis as well as make concise definitions and conceptions of the subject matter herein, thereby conclude.

\section{Thesis}

Over the course of human history, people have developed many interconnected and validated ideas about our world in terms of research, technology and innovation. Many people express the opinion that the tripartite (Research, Technology and Innovation) concepts and global development are discretely parallel. Most of their assumptions take root from sociocultural factors to religious and ethical beliefs. This type of thinkers are those that cast the laws and beliefs of their fore fathers peculiar in the days of yore over the present age; they place the past to the present being less mindful of the great words of Heraclitus, the father of change who said that everything changes except change itself which does not change. Heraclitus opined that the world is in a perpetual state of flux.

So they say that the world which is changing in an exhilarating manner and a lifetime in it can only be a nightmare for many; yet what we seek daily, seems in all ramifications of our human existence is more change. Change, to them is a political jargon, a jazzy incoherence 
filtered out of our collective psyche for better humane environment, better governance and juvenations of moral infrastructures towards a more purposeful existence. No matter how much we seek change, things have remained the same in the backdrop of the growing global moral confusion challenging human ethics and religion. The disobedience of Adam and Eve challenged God's authority and removed from them the sanctifying grace of God's presence.

According to them, research, technology and innovation and global development are adversaries that never go together nor have a meeting point. They are of the stand that one cannot subscribe to the tenets of one without minimizing or totally dismissing the possibility of the other, global development. For them, the three concepts have not only led to global deterioration but have built a citadel of doom for the global village. They are of the opposing view that harm has been done to the world by their inventions which is far from the so-called development that it's intended to achieve.

The invention of nuclear energy has greatly altered social life due to the technological changes. Their views ride on the cycle of changes in the social circle. They attribute underdevelopment to the threatening and terrorizing advent of technological inventions such as nuclear warhead; and postulate that countries that support them are on the speedy track to pandemonium and destruction. Some countries claim that the only way they can maintain peace is to be battle-ready; and because of this notion, the folks who oppose global development through the scientific ways on discussion assert that these nuclear bombs posses the capacity of wiping the entire human race in a twinkle of an eye and as such people now live in dread of the hour, as no one knows when a conflict may arise between nations which may call for the use of this dreadful weapons.

More so, web crimes and dupes, addicts of pornography and character assassinators, internet fraudsters and monsters; all have led the globe to a high level of retrogression in development. In their perspective, development has to do with an alliance and consensus of the ultimate good and human inventions, channeled towards addiction of values and qualities in the pre-existing status quo of an entity. Therefore, any change short of this, mindless of how prodigious it might be, is a severity of development. The country, Nigeria is yet to recover from the menace the extremists called Boko Haram sect had caused in recent time. Such trauma that runs the veins of every Nigerian citizen is ad rem to the postulations of this category of thinkers.

This category of thinkers look beneath the standard for which the technical equipment was made for. They propose the idea that man has used the power of his creativity and innovation to harm his fellow man. Here, scientific works such as research, technology and innovation are portrayed as tools that have led to universal technological shambles that could send any nation to her early grave. They also go a long way to inveighing their voices to their nation al anthem for hope and deliverance from the wafts of morbid scientific works. They yell for liberation from the entanglement of the ubiquitous and hazardous products of research, technology and innovation which snatch their delicious meal on the table of global peace and tranquility.

To make their point more commanding, they so easily dive in to the educational system of the modern students in a modern world full of easy livelihood. They opine that with the advancement of the technological nonsense, students can hardly write good letters, make good speeches and the aforementioned research becomes a mirage because they are too lazy to concentrate and dig deep in to history. Even when they access the internet, they waste whole lots of time visiting and traveling on different nonsensical web pages that have no relevance to life. Social media networks that ought to encourage good human relationship on air are turned to an erotic and bizarre media for the crucifixion of development.

\section{Antithesis}

Very many other great thinkers argue on the contrary proposition; that research, technology and innovation are not only bed rock for global development but catalysts and singers for cosmic reformation and advancement. In our thesis, we could see how fellows heap 
South American Journal of Academic Research

Special Issue May 2016

arguments based on the fact that these scientific concepts are not helpful to man due to various socio-cultural nuisances they constitute. But here, we would understand that wherever there is development, there abound misuses of such developed entity. Less amazing that Barry (1972) argued that "A spiral of technical fixes occurs because of the failure to correct the fundamental flaw that technology is subject to in our society. He says that ' if technology is indeed to be blamed for our environmental crises, it might be wise to discover wherein its 'inventive genius' has failed us and to correct that flaw before entrusting our future survival to technology's faith in itself. Technologies can only become environmentally harmful and indeed problem of man only if they are not properly applied with due sensitivity to the environment". The case is severe where there is no development, as people tend to invent many criminal strategies so as to pull off the food from the rich man's table. So, whether development or not, human crime is inevitable! Albert Eistein corroborates this in his saying that there are two things that can never be changed: the infinity of the universe and the stupidity of the human person.

Research, technology and innovation have gone a long way in helping man improve the quality of his living. In the health sector for example, they help in the production of medicine and treatment of diseases. This means that the methods and instruments used for diagnosing diseases and promoting sanitation and hygiene have aided in the reduction of mortality rate and improvement of the conditions of living. A country which lacks such scientific and technical innovative ideas will have to depend on other countries that were sensible enough to go on research and come up with such developments for existence of her people. Such a nation cannot be referred to as caprices of other nations with necessary science and technology. With research and technological innovations, many medical conditions and procedures that required significant periods of hospitalization before now can be treated or carried out within shortest period of time thus, reducing rapidly the length of hospitalization which in turn reduces costs and risks of infection. With the product of technological innovation and research called 'telemedicine' doctors can now interact, diagnose and treat patients through interactive video and communication equipments that allows viewing and reception of diagnostic data and x-rays (Lee-Roy, 2012). With innovative technology such as assisted reproductive technology, stem cells research and bio-medical technology, infertility is gradually becoming something of the past as there are so many options from which infertile couples can choose from now such as invitro fertilization, artificial insemination, e.t.c

Electrical and electronics: In the sector of electrical and electronics, electronic gadgets which include television and computers cannot be used without the use of electricity. Electricity is needed also in industries for the generation of hydroelectric power supply. The computer which is a remarkable achievement invented, is used for economic activities, administration, education and business and has helped in the reduction of exertion of human energy as more activities can be carried out faster, effectively and more efficiently. Electronic books and electronic paper technology has made electronic media easier to read thus, replacing much paper that runs through the office printer. In addition, telecommuting and video conferencing and online study programmes has significantly reduced the need for transportation and the so many inconveniences that follows it. No wonder Jordan Baruch Associates cited in Lee-Roy (2013) states "Among so-called services, a country's ability to manage and use information will be the single determinant of its rate of development".

In adding values to life; improving the intellectual status of man, research on the other hand helps to increase human knowledge and understanding of events, activities, phenomena and problems existing in his environment. For the folks who oppose the reality of research being the bedrock of global development might find reason here to re-write their theory. When theories are propounded, research helps to provide dependable data which will be used to explain and support such principles or theories (John, 2009).

Economy: The research process leads to better and improved practices in the various spheres of the economy. Results of research works reveal those areas in various professional practices that seem to be ineffective and put forward measures for improving them. For 
example, research has shown that the heavy ultra violet ray and x-rays emitted by machines are detrimental to health as they cause mutation (sudden change in the genetic composition). So, owing to this discovery, efforts have been made to educate radiographers on the protective measures as well as educate the masses who are recipients of radiological examinations to cover themselves with aprons and their likes to avoid the penetration of the hazardous rays. Through research also, it was found that cancerous cells could also be killed with these rays considered hazardous. Further research reveals too, that the rays would not only kill the abnormal cells but also kill the normal ones. So, its concomitant side effects are bound. Many countries today which are regarded as developed countries are called so because over time they have embraced the three unequal concepts of developmental bedrock, namelytechnology, research and innovation (Sharon, 1994).

Environmental protection: In the area of solving environmental problems of man for instance, with the innovations and research in modern technologies we can now reuse substances or objects that otherwise constitutes serious environmental hazards to man, through both air, water and land pollution. With technological innovations, a lot of developmental heights have being achieved. We can now produce automobiles that have less emission of hazardous gases thus, preserve our ozone layer and ecosystem in general while enhancing better conditions for the living. With growth in the economy, there's an increasing opportunity for research-oriented jobs which provide employment of researchers. According to Virginia (2009), the ultimate goal of research is to provide valid answers to questions, valid solutions to problems and to provide new body of knowledge. Research aims at providing insight on existing problems inherent in a system and how to solve them, discovery of facts about a phenomenon, development of new and better instruments and methods employed in various places of work and human endeavours. Most technological breakthroughs are products of research.

Agriculture: According to Richard R. Harwood of Michigan State University, cited in Robert (2004) "Because the world is facing a shrinking land base and growing demand for agricultural products, the output per unit area of the food and feed grains, as well as starchy vegetables, must more than double over next 25 years. While there is considerable scope for increasing yields within the existing genetic potentials, scientific breakthroughs will be needed to fully achieve the needed yields". If the agricultural sector must meet the increasing demand for food, there is every need to embrace new technologies that can increase the yield.

Education: Technology, research and innovation has no doubt made education easy. For instance, with such products as projectors, models, computers and internet facilities, better teaching aids and methods have being embraced which allows the students to have visual concepts of most of what is being taught in class especially in areas of medical and engineering. Technology has reduced the rate of illiteracy globally through online programmes which affords many people the opportunity of being educated while still maintaining their jobs.

\section{Synthesis: towards a conception, explication and fusion of terms}

Having exposed some of the variegated notions of some thinkers in thesis and their antagonistic views in antithesis; here, we shall therefore, marry both arguments and narrow genuine and significant meanings they convey, thereby paint a good picture of global development through research, technology and innovation.

However, efforts have been made never to bend the strong holds of any category of thinker, but to complement and modify their notions we would make effort to strike a balance between the merits and demerits.

\section{Technology}

We can't fully define technology without innovation/knowledge and science. Therefore, we can say that science is the study of knowledge which can be made into a system which depends on seeing and testing facts or can be studied at a closer look on nature and behavior 
South American Journal of Academic Research

Special Issue May 2016

of natural things and the knowledge that we obtain about them; while technology is the activity of using scientific knowledge for practical purposes (the practical application of scientific knowledge). Science deals with imagination and discovery of ideas, while technology is concerned with the creativity and inventions of material which are products of scientific research. Appropriate technology which is defined as " technology tailored to fit the psychosocial and biophysical context prevailing in a particular location and period" is the only panacea for global development ( Willoughby, 1990)

\section{Research}

On daily basis, human beings are faced with numerous problems. These problems are educational, psychological, economical, social, and business-oriented in nature. In order to surmount these obstacles, man has to take definite steps. One of the most important methods of solving problems is through research. What then, is research?

By definition, research is a planned and systemic process of collecting, presenting, analyzing and interpreting data for the purposes of arriving at dependable solutions to human problems (Polit and Beck, 2010). In other words, research is a systematic and objective recording and analysis of controlled observations that may lead to the development of generalizations, principles or theories, resulting in prediction and possibly ultimate control of events.

The perturbing concern of ours now is how the aforementioned concepts have skyrocketed global development. Hold your patience for yet a better explication of the subject matters here. We shall delve in to their roles in global development in the later pages of this write-up.

A good research work has some qualities which counteract some arguments laid by those who oppose the possibility of research, technology and innovation being the bedrock for global development.

One of these qualities is that it must be problem solving in orientation. It must be directed towards solving societal problems for it to be meaningful. So here, we could see that every research work is channeled towards a convergent thinking that would bring forth solutions to our life problems. Maybe, those who argue that research and technology have done more harm than good might not be far from judging wrongly. This is because, for research to be called as so, it must have the ability to provide solutions to our challenging life time situations.

A good research is self-correcting in nature, and has the ability to stimulate further studies. An error might be made in an environment; this would stimulate the inquisitive man to dig deep and find out the rationale behind such anomaly, he would go on further studies and research so as to come back and make a change.

No doubt there is great reliance today on technology to solve both environmental, medical and economic problems of man around the world. But how could such technology with higher capacity for solving man's problems be produced or invented without innovations and research. Technology, research and innovations are three concepts that cannot be easily separated if global development must be attained.

Conclusion: As Robert cited above will always say: “Adopting appropriate technologies leads directly to higher productivity, which is the key to growth. In societies that have large stock and flows of knowledge, virtuous circles that encourage widespread creativity and technological innovation emerge naturally, and allow sustained growth over long periods. In societies with limited stocks of knowledge, bright and creative people feel stifled and emigrate as soon as they can, creating a vicious circle that traps those who remain in a more impoverished space. Such societies stay mired in poverty and dependency". We can at this point rhetorically ask: what can the world do without research, technology and Innovation? These are bedrocks for global developments. 


\section{References}

[1.] Barry, C. (1972) The Closing Circle: Nature, Man and Technology. Bantam Books, Toronto.

[2.] Cramer, j. and Zegveld, W. C. L. (1991) The future Role of Technology in Environmental Management. Futures, Vol.23 No5. Pp461-462.

[3.] Fongwan, S. (2013) The Concept of Globalisation. The Paragon Magazine, Vol. 2 pp. 58

[4.] John, O. (2009) Business Research and Methodology. Meteson Publicity Company, Enugu.

[5.] Jubel D’Cruz (2012) The Best Proverbs. Better yourself Books, Mumbai.

[6.] Lee-Roy, C. (2012) The Role of Science and Technology in the Developing world in the 21st Century. Retrieved from: www.ieet.org/index.phd/IEET/more/chetty20121003

[7.] Lee-Roy, C.( 2013) The Importance of Technology in Economic and Social Development. Retrieved from: www.fairobserver.com/region/africa/importance-technology-economic-and-social development/

[8.] Polit, D. F. and Beck C. T (2010) Essentials of Nursing Research: Appraising Evidence for Nursing Practice. Seventh Edition. Wolters Kluwer Health/ Lippincott Williams and Wilkins.

[9.] Robert, M. W. (2004) Marshaling Technology for Development: Proceeding of a Symposium. National Academy Press.

[10.] Sharon, B. (1994) The Role of Technology in Sustainable Development. Technology and Society, Vol.13, No 4. pp. 14-19.

[11.] Virginia, I. O (2009) Concise Text on Research Methods and Elementary Statistics. 2nd Edition, Ocean Press, New Market Road Enugu.

[12.] Willoughby, K. (1990) Technology Choice: A Critique of the Appropriate Technology Movement. Westview Press, Boulder. 